\title{
A Politics of Peripheries: Deleuze and Guattari as Dependency Theorists
}

Samuel Weeks

Thomas Jefferson University, samuel.weeks@jefferson.edu

\section{Let us know how access to this document benefits you}

Follow this and additional works at: https://jdc.jefferson.edu/jchsfp

Part of the Philosophy Commons

\section{Recommended Citation}

Weeks, Samuel. "A Politics of Peripheries: Deleuze and Guattari as Dependency Theorists."

Deleuze and Guattari Studies, Volume 13, Issue 1, February 2019, Pages 79-103.

This Article is brought to you for free and open access by the Jefferson Digital Commons. The Jefferson Digital Commons is a service of Thomas Jefferson University's Center for Teaching and Learning (CTL). The Commons is a showcase for Jefferson books and journals, peer-reviewed scholarly publications, unique historical collections from the University archives, and teaching tools. The Jefferson Digital Commons allows researchers and interested readers anywhere in the world to learn about and keep up to date with Jefferson scholarship. This article has been accepted for inclusion in College of Humanities and Sciences Faculty Papers by an authorized administrator of the Jefferson Digital Commons. For more information, please contact: JeffersonDigitalCommons@jefferson.edu. 


\title{
Deleuze and Guattari Studies
}

'A Politics of Peripheries: Deleuze and Guattari as Dependency Theorists'

Samuel Weeks, M.A., Ph.D.

College of Humanities and Sciences

Thomas Jefferson University

samuel.weeks@jefferson.edu

This file is the pre-publication version. Here is the citation of the published article:

Weeks, Samuel (2019) 'A Politics of Peripheries: Deleuze and Guattari as Dependency Theorists', Deleuze and Guattari Studies 13.1, pp. 79-103.

DOI: $10.3366 /$ dlgs.2019.0342

https://www.euppublishing.com/doi/pdfplus/10.3366/dlgs.2019.0342

\begin{abstract}
Given that Deleuze and Guattari came to prominence after May 1968, many readers attempt to determine the political significance of their work. The difficulty that some encounter finding its political implications contrasts with Deleuze and Guattari's commitment to radical causes. In response, Patton and Thoburn elaborate on the Marxist elements in the pair's oeuvre, a line of analysis I continue. Focusing on A Thousand Plateaus, I discuss their references to the theorisation of the 'dependency theorists', a group of Marxist-inspired scholars who became influential during the 1960s. Does their engagement with dependency theory provide the basis for a political project?
\end{abstract}

Keywords: Deleuze and Guattari, A Thousand Plateaus, dependency theory, development, alternative globalisations, North-South 


\section{Introduction}

$<\mathrm{T}>$

Given that Deleuze and Guattari came to prominence as collaborators in the aftermath of the May 1968 events in Paris, some readers of $A$ Thousand Plateaus (henceforth ATP) have attempted, often with difficulty, to determine the explicitly political significance of this seminal text. The critics, most prominently Badiou (2000: xii, 2009: 115), find Deleuze and Guattari's Capitalism and Schizophrenia project to be insufficiently Marxist, calling into question the pair's oft-stated inclination towards this political and scholarly tradition. According to this criticism, that Deleuze and Guattari do not seem to develop the forms of organisation needed for political intervention means that they are, at best, ambivalent towards the revolutionary politics specified in Marxist praxis. In this vein, Hallward (2006) faults Deleuze and Guattari for leaving little room for the processes of social and historical transformation and still less for possible political formations of solidarity and resistance. As he asserts in a 2009 debate,

' $<\mathrm{EXP}>$ '

A text like Sartre's 'Colonialism is a System' is designed precisely to get a grip on the issue, to analyse it strategically. Such analysis can enable something like a collective determination to take shape in such a way that it can have a strategic impact and change that situation. It's all about unifying, solidifying, strengthening, focusing - themes opposed to [Deleuze and Guattari's] general logic (Alliez et al. 2009: 144).

In their reluctance to adopt the concepts, practices and formations typical of Marxism, as these critics argue, Deleuze and Guattari are guilty of being apolitical (Badiou 2009a) or worse 'indifferent to the politics of this world' (Hallward 2006: 162). $<\mathrm{NP}>$

The difficulty that these readers of $A T P$ have encountered while trying to find its implications for a political project contrast with Deleuze and Guattari’s longstanding 
engagement with a number of radical causes (Dosse 2010). Guattari, after all, was a committed militant in a number of domestic and international activist circles, from groups espousing unorthodox versions of Marxism (that is, contra those of the French Communist Party and its associated Althusserian tendencies) to movements eschewing the traditional practices of psychiatry and psychoanalysis. Deleuze, while being the less manifestly political of the two, was nevertheless a member of Foucault's Groupe d'information sur les prisons in the early 1970s and a steadfast defender of the Palestinian cause. While critics such as Badiou and Hallward are right to interrogate the heterodox politics promulgated by Deleuze and Guattari, I believe that their criticism does not attest to the depth and complexity of the political engagements spelled out in the pair's work. In the 2009 debate, Hallward himself hints at the numerous radical tendencies found in the dual-authored texts:

' $<$ EXP $>$ '

If you aim to use Deleuze politically then this is the best way to do it: to think about what kind of resources he and Guattari give us for understanding how political composition works, how capitalism works, how political organisations might become more supple and inventive, and so on (Alliez et al. 2009: 153).

$<\mathrm{NP}>$

In response to these provocations, a number of scholars, including (but not limited to) Patton (2000), Lecercle (2005), Tynan (2009), Nail (2012) and Sibertin-Blanc (2016), have elaborated on precisely the elements that Badiou and Hallward accuse Deleuze and Guattari's work of lacking, that is, the concepts, practices and political formations specific to Marxism. As featured in ATP and other texts, these are sometimes apparent and applied in a straightforward manner, but more often than not they are treated in an indirect and unconventional way. Thoburn (2003) has provided perhaps the most forceful 
politico-economic interpretation of the pair's oeuvre. In Deleuze, Marx and Politics, he points to a number of Marxian and Marxist premises in Deleuze and Guattari's work; among others, these include the call for a 'new earth' (Deleuze and Guattari 1983: 382) akin to Marx's vision for a future communist order, their equation of the 'minor' with the proletariat in capitalist society (Deleuze and Guattari 1987: 472) and an active political and intellectual engagement with a variety of radical currents from the 1960s and 70s, most prominently autonomia from Italy and what might be called the 'unorthodox turn' in French leftist critical theory (Lyotard 1974; Baudrillard 1970, 1972, 1973). $<\mathrm{NP}>$

While much else has been written about Deleuze and Guattari's positions on Marxism (for example, Holland 2011), I continue Thoburn's analysis with regards to the radical politics found in $A T P$ and thus join the ongoing scholarly effort analysing the text's many resources for formulating a political project. In particular, I discuss their repeated references to the themes and debates advanced by the 'dependency theorists', ${ }^{i}$ a loosely organised faction of Marxist-inspired scholars that came to prominence in the late 1960s and throughout the 1970s. Influential members of this diverse group of thinkers include economic historian André Gunder Frank (a pupil of Milton Friedman's no less), economist and geographer Samir Amin (whom Deleuze and Guattari cite on seven occasions in ATP), sociologist Fernando Henrique Cardoso (later the president of Brazil) and the world-systems theorist Immanuel Wallerstein. While connections between Deleuze and Guattari and the dependency theorists have been made before, notably by Hardt and Negri (2000), Surin (2009) and Sibertin-Blanc (2016), I will detail and contextualise the references to dependency theory made by the pair in $A T P$, in addition to 
citing several the key elements from this body of work that Deleuze and Guattari omit or reject. My goal in undertaking this analysis is to contribute to the larger scholarly project seeking to understand the depth and complexity of the political implications present in Deleuze and Guattari's texts.

$<\mathrm{NP}>$

Before proceeding to a brief explanation of the bases of dependency theory, I first offer a word on the methodological approach employed in this article. While Deleuze and Guattari never made a specific intervention into the debates of the dependency theorists, there are nevertheless numerous parts in $A T P$ that follow or resemble dependency theory. As is obvious, neither Capitalism and Schizophrenia nor dependency theory are derived from one another; yet if they are understood together, I argue that we can gain a better collective sense of these two radical and compelling ways of thinking. My intervention thus seeks to '[assemble] the heterogeneous fragments' (cf. Nail 2012: 4) of Deleuze and Guattari's engagement with dependency theory. I call these connections 'echoes', ii meaning that Deleuze and Guattari mostly draw from this generalised body of scholarship without explicitly citing its key works. By way of a Foucauldian concept, we could say that dependency theory formed part of the political and intellectual episteme of post-May 1968 France in which Deleuze and Guattari operated. ${ }^{\text {iii }}$ Of the five dependency theorists I discuss (Frank, Wallerstein, Amin, Cardoso and Faletto), Amin is the only one whom Deleuze and Guattari explicitly reference in ATP. Likewise, the pair, to my knowledge, did not engage actively with the texts of the other dependency theorists, nor can it be said that Frank, Wallerstein, Cardoso and Faletto would be likely readers of Deleuze and Guattari. Regardless, it is important not only to analyse the various 
references made to Amin in ATP, but also to Amin's own interlocutors within the field of dependency theory, including Frank, Wallerstein, Cardoso and Faletto.

\section{Dependency Theory: A Brief Taxonomy}

$<\mathrm{T}>$

Before describing the elements of dependency theory that are present in ATP, I will first sketch out this conceptual system's most basic premises. Dependency theory began in the 1960s and 70s as a critique of the 'modernisation' development theories espoused by the Bretton Woods and UN institutions, in particular the latter organisation's Economic Commission for Latin America (ECLA), based in Santiago, Chile. From its origins in the 'boom' years of the post-World War II period, modernisation theory posited that all societies progress through similar stages of development. In a teleological fashion, the theory portrayed the 'underdeveloped' countries of the era as resembling their concurrently 'developed' counterparts at previous moments in the past. To the modernisation theorists, bringing peripheral countries out of poverty entailed 'helping' them along the supposedly common path to development by investing in infrastructure and technology and ensuring their closer integration into the world market. Even though modernisation theory counted many adherents within the ranks of the Global North institutions responsible for maintaining the world economic order, by the mid-1960s it had fallen out of academic favour - in large part due to continued poverty in the countries where its development schemes had been attempted.

$<\mathrm{NP}>$

Among the vanguard of thinkers who formulated specific critiques of modernisation theory were the 'dependency theorists'. This group included a number of specialists who 
were at one point affiliated with the ECLA but who later broke with this UN institution.

Even as their criticisms subsequently went in diverse directions, the dependency theorists were united in their rejection of modernisation theory's teleology of developmental 'stages'. Instead, they believed that underdeveloped - or peripheral - countries are not simply 'primitive' versions of developed ones, but rather feature unique structures and histories of their own and, more crucially, are in the unenviable position of being among the weakest members within the global capitalist order. As such, the dependency theorists examined the marginal situation of the global periphery from the point of view of how external forces produce and condition the internal socio-economic structures of these countries.

$<\mathrm{NP}>$

While it is difficult to speak of 'dependency theory' as if it were a coherent theoretical paradigm, I develop in what follows a brief taxonomy of its main tendencies. As I show later, this collective body of thought provides Deleuze and Guattari with one of the bases necessary for the political interventions they delineate in ATP. Following Foster-Carter (1978), Palma (1981) and Larrain (1989), I will classify - for the sake of explanatory ease - the dependency theorists into two rough groups: the dependentists and the empiricists. Seeking to construct a 'general theory of dependency', the dependentists believe that underdevelopment on the global periphery is the due to the asymmetry that characterises the relations that these countries have with the world's central economies (cf. Lazzarato 2012: 33). For this reason, capitalism itself, according to the dependentists, is unable to bring about a process of equitable development on the global periphery. Thus, the resulting duality of outcomes - by which some countries develop because 
others 'underdevelop' - is due to the transfer of capital, debt and resources through mechanisms of unequal exchange in international markets. Proponents of this version of dependency theory include André Gunder Frank, Immanuel Wallerstein and Samir Amin. $<\mathrm{NP}>$

The second set of thinkers is more 'empirical' in nature, resisting the dependentists' attempt at a general theory and their deep scepticism of capitalism's ability to develop the world periphery. Instead, the empiricists examine the obstacles to development within particular countries - what Fernando Henrique Cardoso and Enzo Faletto call 'situations of dependency' (1979: xxiii) - that stem from external structures and global market conditions. While accepting that the capitalist core exerts an undue influence on the economies of the global periphery, the empiricists analyse historically how a country's domestic relations of production and its class struggles are mediated by external factors. The work of Cardoso and Faletto, notably their classic text Dependency and Development in Latin America (first published in 1970; translated into French in 1978 and English in 1979), is perhaps the best example of the 'empiricist' current within dependency theory. As is shown in the following sections, Deleuze and Guattari draw from the work of the dependentists and the empiricists in $A T P$ at the same time that they implicitly take a number of positions counter to those from the debates that transpired among the likes of Frank, Wallerstein, Amin, Cardoso and Faletto over the years.

\section{Difference, not Repetition}

$<\mathrm{T}>$

Before I proceed to show how Deleuze and Guattari employ in ATP a number of elements from dependency theory, I will first mention some of the decisive points of 
divergence between the pair and the dependency theorists. The first of the concepts not taken up by the pair in $A T P$ is the dependency theorists' conceptual use of linear historical time. In contrast, and without going into too much detail, Deleuze and Guattari draw inspiration from Bergson, Nietzsche and others by showing how time is not made up of a sequence of passing events, but is rather 'an a-temporal bloc where each and every past event co-exists with all the others' (Holland 2013: 18). The dependency theorists such as Frank and Wallerstein, on the other hand, draw on older, more conventional notions of temporality. They recognise that states can - over time - either 'improve' their position in the world system (for example, South Korea, Taiwan and Singapore) or 'digress' within it (Argentina, Iran and Zambia), even as they realise 'that [structurally] within a capitalist world-economy, all states cannot "develop" simultaneously by definition, since the system functions by virtue of having unequal core and peripheral regions' (Wallerstein 1975: 23).

$<\mathrm{NP}>$

Likewise, Cardoso and Faletto (1979) detail the chief economic transition that took place within Latin American countries at the beginning of the twentieth century: from economies based solely on the exportation of raw materials to ones featuring a mix of industry and exports. As they explain, this shift in emphasis provoked numerous crises within Latin America, as the new ruling classes - the industrial and comprador bourgeoisies, in tandem with technocratic government elites - sought to re-organise their political economies in favour of manufacturing. Frequently couching their efforts in nationalist terms, these emergent domestic forces attempted to stave off a position of permanent backwardness as the 'unproductive' exporters of raw materials to the central 
economies of the world system (cf. Goodchild 1996: 120). For a while, the national projects of this new class alliance proceeded according to plan - even spectacularly so, in the cases of Brazil and Argentina. However, as Cardoso and Faletto demonstrate, each one of these countries eventually succumbed to crisis, as the conditions necessary within the global system for widespread industrialisation had changed radically (for example, the rise of 'free trade', use of advanced proprietary technologies, reductions in shipping expenses and so on). What had been a delay in the industrialisation process at the periphery had thus become entrenched underdevelopment.

$<\mathrm{NP}>$

As seen the italicised words in the previous paragraph - that is, Cardoso and Faletto's references to chronological transitions, intentionality, causality, hierarchical achievement and social change - run counter to many of the notions of temporality that Deleuze and Guattari forward in $A T P$, such as 'becoming', 'stratification' and 'contingency', among others. For Cardoso and Faletto, time is linear, calculable and 'reversible', in the sense that their political project is to undo centuries of economic dependency and underdevelopment at the world periphery. For Deleuze and Guattari, in stark contrast, time implies emergence and irreversibility; in $A T P$, the past is presented as an omnipresent whole, not a series of occurrences strung out on a line, as is found in Cardoso and Faletto's 'historical-structural' approach to dependency theory. Deleuze and Guattari thus favour non-linear movement between moments in the past, without having to outline or situate these within an empirical scheme or timeline. ${ }^{\text {iv }}$ $<\mathrm{NP}>$ 
A second tendency emphasised by the dependency theorists but not Deleuze and Guattari is the role within the world system of luxury commodity consumption by elites in peripheral countries. Among the former group of thinkers, Amin (1976) is the one to develop this factor in the most detail, highlighting a two-part process that leads to overall 'unequal development' in the world system. According to his account, the exploitation of Global South countries is largely due to the core economies extracting sizeable amounts of the surplus created at the world periphery. Another aspect of this process is the squandering by 'backward oligarchies' of the small part of the surplus that remains on the periphery, a phenomenon that usually takes the form of luxury consumption. In other words, elites on the periphery fail to reinvest their revenues from international trade, but instead waste them in acts of conspicuous consumption, thus forming a captive market that purveyors of luxury goods in the core countries are eager to exploit. Amin asserts, as a result, that it is in part due to the loss and misuse of their economic surplus that peripheral countries become underdeveloped. Larrain relates this phenomenon to the contradictory nature of consumption at the global periphery:

' $<$ EXP $>$ '

Because super exploitation means that the local working class is practically excluded from the consumption of manufactured products, a double sphere of consumption is created: luxury consumption for the few members of the ruling classes and subsistence consumption for the majority of the workers (1989: 118).

This failure to re-invest capital at the periphery, in turn, puts additional pressure on the few 'successful' export sectors in place (usually in raw materials), resulting in a nondiversified economy that is almost entirely at the whims of global commodity prices. In contrast, Deleuze and Guattari's omission of the structural role played by elite consumption is likely due to their hesitancy to adopt in total the Marxist framework of 
class. In $A T P$, the pair downplays the existence of any fixed economic identities or groups, due to the pervasiveness and dynamism of capitalism across the social whole. $<\mathrm{NP}>$

Not limited to their hesitancy to employ the Marxist understanding of class, Deleuze and Guattari's overall unconventional engagement with Marxism distances them further from the dependency theorists, in particular Cardoso and Faletto and their 'historicalstructural' analysis of class struggles in certain Latin American countries. Along these lines, Cardoso and Faletto downplay any notions of dependency as solely due to external causes, a tendency that separates their work from the thinking of Frank, Wallerstein and Amin. While Cardoso and Faletto do take into account the dynamics of the world system, their analysis instead focuses on "the historical transformation of structures by conflict, social movements, and class struggles' (1979: x). To these authors, dependency is not simply an 'external' factor leading to internal consequences, but rather is a pervasive condition that manifests itself through domestic class conflict. They write, 'an understanding of the strong inequalities characterizing these structures [of Latin American economies], as well as an explanation of the exploitative process through which these structures are maintained, require the analysis of the system of production and the institutions of appropriation' (Cardoso and Faletto 1979: x). Having established these parameters as the focus of their analysis, Cardoso and Faletto proceed to survey three centuries of history in various Central and South American countries. In these cases, they look for how factions of political and business elites seek internal alliances with segments of the middle classes, the proletariat and even indigenous and mestizo peasants in order to protect their interests from foreign control and competition. For these 
authors, what is at stake is the nature of class struggles and the political manoeuvring that takes place within situations of external dependency. $<\mathrm{NP}>$

Having noted some points of discordance between Deleuze and Guattari and Frank, Wallerstein, Amin, Cardoso and Faletto, the pair's decision to highlight a number of the concerns of the dependency theorists seems curious. While Deleuze and Guattari never made a specific intervention into the merits of dependency theory, it is clear that the pair would diverge even further from the likes of Frank, Wallerstein, Amin, Cardoso and Faletto with regards to how this latter group of thinkers conceives the concepts of development and the nation-state. First, as noted by Larrain (1989: 188-90), 'development' to the dependency theorists is a question that is for the most part unproblematised. In this regard, 'dependency' seems as vulnerable to critique from Deleuze and Guattari as were the Marxist, structuralist and psychoanalytic orthodoxies that the pair challenge throughout their Capitalism and Schizophrenia project. Surely Deleuze and Guattari would take issue with the simplistic binary of 'development' and 'underdevelopment', in which 'development' is the non-problematic condition and 'underdevelopment' is conceived of as its reverse (Sibertin-Blanc 2016: 204). Ironically, this rather crude opposition even mirrors the modernisation theory that the dependency theorists so vociferously rejected, as both theories cite a preferred model of development then assess the 'backwardness' of the periphery in relation to it. Likewise, akin to how modernisation theory predicts development for the periphery by means of repeating the process already undertaken by the developed countries, dependency theory - in a 
similarly determinist fashion - foretells the opposite scenario: the impossibility of any 'advancement' among the peripheral countries of the world system (cf. Frank 1969: xv). $<\mathrm{NP}>$

In a similar fashion, as theorists and proponents of 'nomadology', Deleuze and Guattari reserve a conceptual aversion for the form and organisation of the modern nation-state. However, as they would most likely point out, the very framework of the nation-state underpins dependency theory, such that it is theoretically incapable of transcending the national economy as a unit of analysis. In this light, dependency theory follows bourgeois economics in its valorisation of 'national development', a concept long thought to transcend class interests, yet is one that has often been mobilised to subdue radical workers' movements, diverting attention away from local class struggles towards chimerical threats of 'external enemies' (Larrain 1989: 192). As is obvious, Deleuze and Guattari would rebuff the dependency theorists' simplistic treatment of the nation-state in the same way that they would object to the more teleological assumptions implied in the concept of development.

\section{The Development of Dependency}

$<\mathrm{T}>$

Thus far, we have seen how Deleuze and Guattari do not employ in ATP a number of the central elements of dependency theory. In the following sections, I will do the opposite, citing some key concepts from this scholarship that the pair takes up in the text. The first of these parallels regards the development of the unequal exchange and uneven geographic development that mark the contemporary capitalist order. Although Deleuze and Guattari eschew linear notions of temporality in $A T P$, they nonetheless reference the 
historical basis of unequal exchange within the world system. In fact, the pair is explicit when they say that the continued asymmetry found between states of the Global North and South is 'bequeathed by the old colonialism' (1987: 465; cf. Sibertin-Blanc 2016: 205). To describe these dynamics, Deleuze and Guattari employ their concept of 'striated space' to discuss the West's colonisation of the rest of the world: 'one of the reasons for the hegemony of the West was the power of its State apparatuses to striate the sea by combining the technologies of the North and the Mediterranean and by annexing the Atlantic' (1987: 387). More specifically, Deleuze and Guattari mention the plight of the Ottoman Empire in relation to the emerging politico-economic supremacy typified by the Western colonial powers. Itself a controller of territories, the modern-era Ottoman Empire nevertheless became increasingly peripheral to its rapidly industrialising European neighbours. While its official demise did not come until after World War I, the Ottoman state declined throughout the nineteenth century because, as Deleuze and Guattari argue, it 'met capitalist demands with too much resistance and inertia' (1987: 436).

$<\mathrm{NP}>$

In a similar fashion, Deleuze and Guattari echo the dependency theorists in how they view changes in a particular country's 'axioms', or politico-economic formations, within the context of developments in the world capitalist order. To quote the pair at length:

' $<$ EXT $>$ '

There is a tendency within capitalism continually to add more axioms. After the end of World War I, the joint influence of the world depression and the Russian Revolution forced capitalism to multiply its axioms, to invent new ones dealing with the working class, employment, union organization, social institutions, the role of the State, the foreign and domestic markets. Keynesian economics and the New Deal were axiom laboratories. Examples of the creation of new axioms after the Second 
World War: the Marshall Plan, forms of assistance and lending, transformations in the monetary system. It is not only in periods of expansion or recovery that axioms multiply. What makes the axiomatic ${ }^{\mathrm{v}}$ vary, in relation to the States, is the distinction and relation between the foreign and domestic markets. There is a multiplication of axioms most notably when an integrated domestic market is being organized to meet the requirements of the foreign market (1987: 462).

An analogous form of inquiry exists in the work of Cardoso and Faletto. In their examination of the industrialisation processes that took place during the $1950 \mathrm{~s}$ and $60 \mathrm{~s}$, the authors bemoan 'the new nature of dependency' (1979: 149) that came to characterise the Latin American economies of this period. Akin to Deleuze and Guattari asserting that changes taking place within a particular country are provoked by 'requirements of the foreign market' (1987: 462), Cardoso and Faletto lament how the increasing ‘internationalisation' of Latin America's economies resulted in 'multinational' (that is, Global North) corporations controlling the continent's most dynamic sectors. $<\mathrm{NP}>$

Similar to how they relate the growth of capitalism to political change, Deleuze and Guattari also follow the dependency theorists in emphasising the spatially uneven nature of capitalist development, a condition that is particularly acute at the periphery. The pair writes,

$'<$ EXT $>$ '

This explains the existence, at the periphery, of heteromorphic social formations, which certainly do not constitute vestiges or transitional forms since they realize an ultramodern capitalist production (oil, mines, plantations, industrial equipment, steel, chemistry), but which are nonetheless pre-capitalist, or extra-capitalist, owing to other aspects of their production and to the forced inadequacy of their domestic market in relation to the world market (1987: 436).

The limited extent of capitalist development on the world periphery, situated amidst other systems of production, is a central aspect of Cardoso and Faletto's analysis of Latin 
America's economies, which first came to prominence in the late 1960s - more than a decade before the publication of ATP. Compare the previous passage by Deleuze and Guattari with the following quotation from Cardoso and Faletto:

' $<$ EXT $>$ '

Although there is the possibility of modernizing the industrial sector and of diversifying it through the international monopolistic production unit, these 'islands of modern industry' are inserted into a context [defined by] the old agro-exporting society with its two subgroups (agro-commerical and latifundista) (1979: 164).

As shown, both sets of thinkers contend that global capitalism requires and fosters a heterogeneous assemblage of productive formations within particular states and at the global level. This dynamic thus obliges peripheral states to have multiple points of 'linkage' so that they can connect with the economies of the centre (Lecercle 2005: 42).

As a result, countries on the periphery are defined by a co-existence of capitalist structures (for example, advanced infrastructure, high technology, transit routes, bureaucracies and so on) and non-capitalist forms of social organisation. Across this fragmented topography, certain industries, social classes and areas are closely integrated within the world system, while other activities, groups and regions are largely excluded from capitalist development. As Deleuze and Guattari infer in the above passage, underdeveloped countries are those in which the latter sectors, classes and areas predominate, in other words, those entities that are marginalised and excluded from the process of 'development' under global capitalism.

\section{The World System}

$<\mathrm{T}>$

A central tenet of dependency theory mentioned repeatedly in $A T P$ regards the totalising nature of global capitalism. Among the dependency theorists, Frank was the most 
adamant about this aspect of the world system. Rather than there being a 'Japanese capitalism', a 'South African capitalism' and the like, he stresses the asymmetrical interconnectedness of the countries at the core and periphery of the global economic order (Foster-Carter 1978: 49). Frank begins with the premise that capitalism arose in northwestern Europe and succeeded to incorporate all of the world's societies into a single international order. This system, in turn, became a 'whole chain of metropolises and satellites, which runs from the world metropolis down to the hacienda or rural merchant who are satellites of the local commercial metropolitan center but who in their turn have peasants as their satellites' (Frank 1969: 146-7). Similar to Frank, Deleuze and Guattari admit that individual nation-states can have markedly different economies (for example, Germany and Togo), though they underscore that these supposedly disparate parts of the world system converge to form an integral capitalist order:

\section{' $<$ EXT $>$ '}

We can join [dependency theorist] Samir Amin in saying that the axioms of the periphery differ from those of the center. And here again, the difference and independence of the axioms in no way compromise the consistency of the overall axiomatic. On the contrary, central capitalism needs the periphery constituted by the Third World, where it locates a large part of its most modern industries; it does not just invest capital in these industries, but is also furnished with capital by them (1987: 465; emphasis added).

Even as these distinct politico-economic spaces retain their own relations of production, they are also forced to interact with other, more powerful productive systems. For Amin, 'domination [is] the basis of this unity' (1977: 190). Thus, according to Amin (and Deleuze and Guattari), the capitalist world system tolerates alternative politico-economic systems at the periphery which can keep elements of their identity insofar as they are dominated by the overall axiomatic (cf. Frank 1978: 254). ${ }^{\text {vi }}$

$<\mathrm{NP}>$ 
Helping to bring together these disparate economic formations, as Deleuze and Guattari stress, is the state, a 'model of realization' (1987: 455) for capital. Whereas capitalism expands its scope ad infinitum regardless of localised social specificities, hence achieving a 'superior deterritorialisation' in Deleuze and Guattari's idiom, the state groups together and combines several axioms in order to control the inherent dynamism of capital, thus 'reharnessing and reorganizing flows which capital brings together' (Surin 2009: 252). The combination of capital and the states of core countries, in turn, results in an assemblage that ensures global domination for the capitalist order. As a 'multinational ecumenical organization' (Deleuze and Guattari 1987: 453), capital mobilises its skill and resources in ways that ensure a fundamental 'isomorphy' between the various state formations of the world system. To describe this tendency, Deleuze and Guattari use the term 'isomorphy' to refer to the interactions between the world's diverse politicoeconomic formations - each of which possesses varying levels of power and resources. They claim, 'there is isomorphy between the United States and the bloodiest of the South American tyrannies (or between France, England, and West Germany and certain African States)' (1987: 465). As an example of 'isomorphy', Deleuze and Guattari analyse the place of the Warsaw Pact countries within the capitalist world system:

' $<$ EXT $>$ '

Even the so-called socialist States are isomorphic, to the extent that there is only one world market, the capitalist one... capital as a general relation of production can very easily integrate concrete sectors or modes of production that are non-capitalist... the bureaucratic socialist States can themselves develop different modes of production that only conjugate with capitalism (1987: 455).

As Deleuze and Guattari make clear, socialist states are nevertheless still situated within the domain of the global capitalist axiomatic. The pair thus follows Frank and Amin in 
showing how the overall world system retains its capitalist nature regardless of the specific productive formations that combine to constitute it.

\section{Conditions of Inequality}

$<\mathrm{T}>$

Having sketched the contours the world system, Deleuze and Guattari then go about defining its characteristics, in particular the many asymmetries that exist with regards to capital flows and debt levels, the terms of global trade and the governance of the world capitalist system. As before, the pair's work resembles that of the dependency theorists, in particular Cardoso and Faletto. Quoting French economist Michel Lelart, Deleuze and Guattari write,

$'<$ EXT $>$ '

Movements of capital do not allow themselves to be segmented... because they are 'the most thoroughly broken down, according to their nature, duration, and the personality of the creditor or debtor', one 'no longer has any idea where to draw the line when dealing with these flows' (1987: 217).

$<\mathrm{NP}>$

Unnerved by this 'floating' nature of global currencies, Deleuze and Guattari recognise where power lies in the world capitalist system: "when we talk about banking power, concentrated most notably in the central banks, it is indeed a question of the relative power to regulate "as much as" possible the communication, conversation, and coadaption of the two parts of the circuit' (1987: 217). In this passage, Deleuze and Guattari touch upon a central concern of the dependency theorists: the omnipresent governance of world capitalism and 'the asymmetry inherent in [its] economy of debt' (Lazzarato 2012: 73). Using country case studies, Cardoso and Faletto detail the process by which Latin American governments - which '[contract] new loans that... swell its debts with 
international financiers' (1979: 41) - became obliged to deal with the governing institutions of global capitalism, namely the IMF, World Bank, WTO and the US Department of the Treasury. The authors trace the influence of these institutions in Latin America back to the establishment of the Roosevelt Corollary to the Monroe Doctrine in 1904. With this act, President Theodore Roosevelt declared that if a Latin American state became remiss in paying off its debts, only the US government could compel that state to make the reforms necessary to reach a settlement (Cardoso and Faletto 1979: 63). $<\mathrm{NP}>$

These interventionist and imperial tendencies of the US became even more pronounced in the aftermath of World War II. The 1944 Bretton Woods Agreement - which turned the US dollar into the world's reserve currency, in addition to establishing trade and tariff accords (GATT) and mechanisms of monetary control (IMF) - brought the world capitalist system under US stewardship and dominance (cf. Sibertin-Blanc 2016: 201). As a result, the US duly assumed the role of being the bankers, stockholders, managers and police officers of the global economy. In exchange for its corporations and treasury department being able to reap monopoly profits in the post-war world, the US provided 'the West' protection against the Soviet Union, access to industrial and military technology and overall defence of the capitalist system. $<\mathrm{NP}>$

Given that $A T P$ was written during the Cold War, Deleuze and Guattari draw parallels between the processes of militarisation with developments in the world capitalist system, yet another tendency that they share with the dependency theorists. The pair alludes to 
the policy of 'mutually assured destruction' between the US and USSR and speaks of its domestic ramifications:

$'<$ EXT $>$ '

The overarmament of the West and East... gives [the world powers] a new force and new stakes; it [founds] the 'apocalyptic' possibility of a direct confrontation along the two great axes... As for the aim, it remained the political aim of the States... to make war a 'total war' (1987: 466).

In a similar manner, Cardoso and Faletto detail this trajectory for the US in the postWorld War II period. Military victory ushered in a period of economic dynamism for the US, as might be expected for an oligopolistic economy of large enterprises buoyed by the technological achievements of the war period. There were ramifications, however, for this apparent success: 'The price paid for this position - especially in the Cold War climate - was the militarization of the American economy' (Cardoso and Faletto 1979:

181). Likewise, Deleuze and Guattari note the importance of military expenditure to state entities:

$'<$ EXT $>$ '

The military institution is from the start one of the most effective means of absorbing surplus... [and] keeps the metallurgists, both craft and mercantile, within strict bounds, under powerful bureaucratic control, with monopolistic appropriation of foreign trade in the service of a ruling class (1987: 450; cf. Harvey 2007: 84).

As a result, not only is the 'military-industrial complex' a way for the US to secure a position of power within the world system, but it is also a means to utilise surplus capital and labour within its economy, in addition to providing the state an opportunity to establish more pervasive means of social control among the population (Deleuze 1992; Patton 2000: 98). Deleuze and Guattari warn, however, that it is not possible for a single country - the US in this instance - to keep armies overseas and invest abroad without 
neglecting the '[Global] Souths or Third Worlds inside the center' (1987: 468), that is, populations of minorities, youth and precarious workers.

$<\mathrm{NP}>$

In addition to citing how the 'military-industrial complex' becomes a recipient of surplus capital within the world system, the dependency theorists also point to the nefarious political role played by authoritarian military elements in the economies of peripheral countries. This argument mirrors Deleuze and Guattari's discussion of how military domination was central in helping the Despot pursue (his) political objectives, namely subduing the 'war machine' and forcing previously nomadic populations to become sedentary, produce surplus goods and pay tribute. In an analogous fashion, as documented by Cardoso and Faletto, authoritarian intervention - often aided logistically and diplomatically by the governments of the core countries - was common in Latin America during the 1960s and 70s, with Brazil, Argentina and Chile being the paradigmatic cases. When the post-World War II 'developmentalist' projects of many of the Latin American countries reached points of crisis, increasingly authoritarian measures became 'necessary' to manage the consequences of uneven industrialisation: a growing concentration of wealth, the marginalisation of large factions of the population and the rise of political movements dedicated to socialism or more radical forms of nationalism. The rigid tactics employed by these authorities included large doses of fiscal austerity, severe restrictions on trade union activity and unbending accommodation to the needs of foreign capital. As Cardoso and Faletto demonstrate, alliances of elites in peripheral countries sought a more authoritarian and centralised state in order to consolidate their domination and insure military protection for their exploitative economic practices. The 
pair assert, 'military influence [was] advanced as a necessary condition for development and national security; and military interference in economic, political, and social life [was] dressed up to appear as a kind of technocratic arbitration' (Cardoso and Faletto 1979: 167).

\section{Becoming-surplus}

$<\mathrm{T}>$

Throughout ATP, Deleuze and Guattari bemoan the 'machinic enslavement' (1987: 428) present in the global capitalist order, a condition they liken to the slave labour employed by the Despotic States of antiquity, the "first great mega-machine[s] of capture and accumulation' (Holland 2013: 134). In describing this condition, the pair references repeatedly the plight of workers, in particular how these producers of surplus-value become parts of a social machine devoted solely to the accumulation of capital. In the 'Apparatus of Capture' plateau, Deleuze and Guattari define the process by which rents accrue to the owners of capital; rather than by slavery, as was the case under the Despot, the appropriation of surplus instead takes place under a more indirect - but no less reprehensible - regime: wage labour. They write,

' $<$ EXT $>$ '

We shall call Capture this difference or excess constitutive of profit, surplus labor, or the surplus product: 'Nominal wages include everything, but the wage-earners retain only the income they succeed in converting into goods; they lose the income siphoned off by the enterprises' (1987: 446; italics in original).

$<\mathrm{NP}>$

The appropriation of surplus-value - a process to which Deleuze and Guattari allude in their concept of 'capture' - has been, after all, a central concern to generations of Marxists, a group that includes many of the dependency theorists. Scaling up this 
Marxian notion to the level of nation-states, Frank laments the 'expropriation and appropriation of a large part or even all of and more than the economic surplus or surplus value of the satellite by its local, regional, national or international metropolis' (1969: 147). As an example, Frank mentions that in the case of Brazil there was a net capital outflow to the US of \$1.6 billion between 1947 and 1960 (Frank 1969: 150). Because interests in the core countries control decisions regarding production, 'capture' represents the value siphoned off from the periphery that goes to swell the capital funds available in the central economies (cf. Surin 2009: 121).

$<\mathrm{NP}>$

Furthermore, because 'investment' originates in the core, such that any surpluses that accrue return to the foreign source, so too can this capital be withdrawn from the peripheral country in question at a moment's notice. Deleuze and Guattari write, 'a multinational corporation can at will plan the liquidation of a factory inside a country' (1987: 463-4). They go on to discuss the controlling effects that this threat of 'capital flight' has on the sphere of the political, in particular on radical working-class movements. Within the globalised capitalist system, such a threat constitutes a pervasive source of domination in the political realm, a phenomenon Lazzarato refers to as 'social subjection' (2012: 146). The owners of capital thus utilise this sentiment to their advantage, turning the 'satisfactory operation of markets' into one of the principle instruments of social control in the contemporary world.

$<\mathrm{NP}>$

Another indicator of our current socio-economic malaise foreseen by Deleuze and Guattari concerns the development in the Global North of what is now called the 
'precariat'. The pair describes the conditions for the formation of this class using the vocabulary of the dependency theorists:

' $<\mathrm{EXP}>$ '

States of the center deal not only with the Third World, each of them has not only an external Third World, but there are internal Third Worlds that rise up within them and work them from the inside... peripheral zones of underdevelopment inside the center, internal Third Worlds, internal Souths. 'Masses' of the population are abandoned to erratic work (subcontracting, temporary work, or work in the underground economy), and their official subsistence is assured only by State allocations and wages subject to interruption (1987: 469).

Deleuze and Guattari's discussion of what would later become known as the 'precariat' using the terminology of the dependency theorists is not coincidental, for this latter group made some of the first attempts to document situations of 'internal colonialism' and 'subimperialism' among the countries of Latin America. For example, Cardoso and Faletto describe the case of the Sudeste, or the 'richer' southeastern Brazilian states of São Paulo, Rio de Janeiro and Minas Gerais, acting as an internal coloniser of the nine states comprising the country's relatively impoverished northeast region (Nordeste). As they note, a marked 'dualism' can be seen over these two areas - that is, the uneven and fragmented nature of development under capitalism (Cardoso and Faletto 1979: 198). Indeed, the vast disparities between Brazil's Sudeste and Nordeste in terms of the balance of trade, surplus extraction, levels of infrastructure and investment and trajectories of migration resemble the inequalities seen at the global level between the countries of the core and periphery.

\section{Conclusion}

$<\mathrm{T}>$

Given the pair's unconventional positions on Marxism, linguistics, psychoanalysis, history, aesthetics, geography and semiotics, among other fields, it would be naïve to 
expect Deleuze and Guattari to follow all of the premises of dependency theory, a total engagement not even found among the likes of Frank, Wallerstein, Amin, Cardoso and Faletto. Nevertheless, the pair did interact considerably with this system of thought, to an extent similar to their concomitant readings of the works of Italian Marxist autonomia current (Thoburn 2003) and the 'anarchism'-inspired ethnography of Pierre Clastres (Viveiros de Castro 2010). In what follows, I show how the pair uses aspects of dependency theory as an additional radical political current in ATP. The major components of this scholarship they utilise are the persistence of asymmetries dating from the colonial era, the integral nature of the capitalist order, the heterogeneity that marks the peripheral and core areas of the world system and the tendency of surpluses to be captured from within the flows of global commerce. Moreover, it is certain that both Deleuze and Guattari and the dependency theorists favour 'a non-economistic reading of the economy, a reading not based on exchange but rather on an asymmetrical creditordebtor power relation' (Lazzarato 2012: 72). As should also be expected with Deleuze and Guattari, however, the pair omits some key tenets of dependency theory - for example, its Marxist-inspired conceptions of history and class struggle - while rejecting (implicitly) others, namely the use of 'development' and the 'nation-state' as two principal units of analysis.

$<\mathrm{NP}>$

The pair's recurring engagement with dependency theory in ATP does, pace Badiou and Hallward, point to some specific areas of intervention for a possible Deleuzo-Guattarian political project. Both Deleuze and Guattari and the dependency theorists conclude that even as countries feature differing forms of socio-economic organisation they are always 
assimilated into the global order of capitalism. Similar to the position of Marx 100 years earlier, all the thinkers discussed herein acknowledge the protean and dynamic character of worldwide capitalism, even as they recognise the necessity of disrupting its violent and exploitative nature. The challenge thus becomes how to formulate a revolutionary politics that can overcome the might of global capital and its ruinous 'economy of debt' (Lazzarato 2012: 96) with an eye to creating genuinely 'popular' forms of social organisation.

$<\mathrm{NP}>$

Once again, the thought of Deleuze and Guattari and that of the dependency theorists converges upon some political and conceptual strategies for achieving this aim. In Critique and Anti-Critique (1984), Frank posits that real revolutions on the global periphery must first require political independence by means of a 'delinking' from the core capitalist countries. As he insists, the scope and power of multinational capital make the establishment of autonomy a must if imperial ties with the centre are to be severed. Only by delinking from global capitalism can peripheral countries develop the kinds of social and economic organisation more appropriate to the needs of their populations. Frank also asserts that delinking can create the internal political conditions necessary for combating socio-economic inequality, a logic which can later be used to structure any dialogue with representatives from the institutions of global capitalism. The overarching aim for the process of delinking is thus to find alternatives to the hegemonic 'structural adjustment' policies advocated by the core countries, which oblige peripheral governments to tailor their agendas to the demands of international capital, to the detriment of the social, cultural and economic interests of a majority of their inhabitants. 
$<\mathrm{NP}>$

Continuing Frank's line of analysis, Amin, in Delinking: Toward a Polycentric World (1990), concludes that only with political autarky can the global periphery possess any basis for autonomy on social and economic matters. He asserts that the decision to maintain or sever 'linkages' with the capitalist system should be entirely pragmatic - 'Is X really to our people's benefit or not?' - and be based strictly on particular interests within the peripheral country in question. Amin simplifies the calculus: the arrangements bringing the fewest benefits and extracting the greatest costs should be discontinued immediately. If these steps were to be taken en masse, he supposes, then the policies of institutions such as the IMF, WTO and World Bank would need to be revised, thus putting peripheral countries in a better position to implement development projects that are endogenously oriented, as opposed being solely at the whims of financial markets that have them 'by the throat' (Surin 2009: 127).

$<\mathrm{NP}>$

Not only do Deleuze and Guattari seem to converge on these positions of Frank and Amin, the pair also offers a potent concept that could underlie efforts at the periphery to 'delink' from the core: the war machine. In fact, any possible political and theoretical rapprochement of Deleuze and Guattari and the dependency theorists must involve aligning the dynamism of the war machine to the radical project of delinking. Comprised of thought and action that is situational rather than scientific, the war machine 'appeals to a people instead of taking itself for a government ministry' (Deleuze and Guattari 1987: 378). This revolutionary device operates at the periphery en plein air with whatever resources happen to be at hand, rather than adhering to the supposed 'laws' or 'science' 
formulated by the sedentary states and their apparatuses of capture at the core of the world system. In the words of Patton, the war machine implies a 'theoretical domain conceived as a milieu, rather than a territory, within which we may assemble and deploy whatever kinds of theoretical apparatus may prove useful, or necessary to the enterprise in which we are engaged' (1988: 132). The war machine, then, is neither possessed by a particular group or current nor maintained by a vanguard party, but rather is a 'a mode of engagement, an open set of political parameters and techniques, and a site of problematisation' (Thoburn 2003: 9).

$<\mathrm{NP}>$

Thus, the tactics and disposition of the war machine will no doubt be essential in any attempt at the periphery to delink from the core capitalist institutions. As Deleuze and Guattari warn, however, there are no pre-given laws or guarantees to shape this outcome, either at the periphery or in the core; only by struggle and experimentation, and the failure that always accompanies any success in this process, can the desire to 'delink' be fulfilled (Surin 2009: 261). As it builds, the political project of delinking might even be turned into a global war machine of revolution, one 'of smashing capitalism, of redefining socialism $[\ldots]$ whose aim is neither the war of extermination nor the peace of generalized terror, but revolutionary movement' (Deleuze and Guattari 1987: 472-3). The lone alternative offers little consolation: acceptance of a profoundly asymmetric world system that continues to be marked by US hegemony, an exploitative 'debt economy' (Lazzarato 2012: 20) and 'neo-imperialist wars of that criminalize any force of contestation' (Sibertin-Blanc 2016: 92).

$<\mathrm{NP}>$ 
In conclusion, by employing a number of important ideas from the repertoire of dependency theory, Deleuze and Guattari again disprove their more trenchant critics' assertions (for example, Badiou 2000; Hallward 2006) that their work lacks specifically political registers of thought. In this light, we can interpret Deleuze and Guattari's inclusion of dependency theory in ATP to be a 'war machine' against the forces of technocratic elitism and in favour of a 'delinking' politics that seeks to create more equitable forms of social organisation. Furthermore, the pair shares the belief of the dependency theorists that peripheries can be the sites for mobilising a revolutionary politics. As such, these thinkers strongly believe that even a global revolution might emerge from the smallest of political experiments on the margins of the world system (cf. Nail 2012: 4).

$<\mathrm{NP}>$

In the aftermath of the May 1968 events in Paris, Deleuze and Guattari came to the realisation that the traditional industrial working class could no longer be considered the primary agents of revolution. Out of this impasse, they looked not simply to the proletariat of industrialised countries, but rather foresaw a linkage of this group with the broader pool of the dispossessed and disaffected in core and peripheral countries alike. Deleuze and Guattari thought that this much larger collective political assemblage - all exploited by capital and essential to the reproduction of the current world system possessed more room to manoeuvre in order to 'construct revolutionary connections in opposition to the conjugations of the axiomatic' (1987: 473). Using Hardt and Negri's terminology, 'the creative forces of the multitude that sustain Empire are also capable of autonomously constructing a counter-Empire, an alternative political organization of 
global flows and exchanges' (2000: xv). With this idea of revolution, Deleuze and Guattari once again resist the conceptualisation of politics as taking place on a single strategic plane and instead conceive of 'revolutionaries' to be those at the world system's many peripheries who embody a pervasive, if diffuse and heterogeneous, desire for liberation. It is this emphasis - conceptualising a revolutionary politics that draws its strength from the periphery - that is central to the pair's engagement with dependency theory in $A T P$.

\section{Notes}

i 'Dependency theory' was a term that some of these thinkers embraced and others resisted, for different reasons. For the sake of simplicity, I lump the 'dependency theorists' together, though in the following section I elaborate on the range of positions this group held.

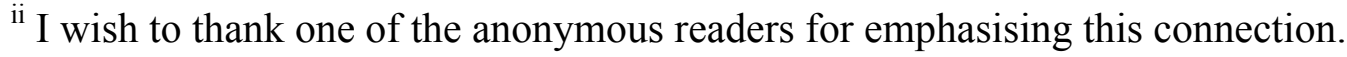

iii Apart from Amin, whom Deleuze and Guattari explicitly cite, the connections I draw between passages of ATP and the remaining dependency theorists cited herein - Frank, Wallerstein, Cardoso and Faletto - is not to say that the text definitively draws on these four thinkers and not from others working in this tradition of scholarship. Thus, so as to resolve the issue of which theorists to include, I consulted three definitive accounts of dependency theory, those by Foster-Carter (1978), Palma (1981) and Larrain (1989); after close examination, I realised that Frank, Wallerstein, Amin, Cardoso and Faletto are the only major dependency theorists to be cited in all of the three aforementioned overviews. Furthermore, I base this decision on my judgement as a reader of this scholarly corpus. While not representative of the entirety of the respective schools of thought within dependency theory as a whole, the writings of Frank, Wallerstein, Amin, Cardoso and Faletto nevertheless provide a sense of the variety, refinement and even divergences within the scholarship.

${ }^{\text {iv }}$ I should note that the 'universal history' constituting the third part of Anti-Oedipus (1983) does, in fact, read in a linear fashion, even though Deleuze and Guattari explain that this version of temporality is only possible from the vantage point of contemporary capitalism. I thank the other anonymous reader for reminding me of this divergence.

'I take 'the axiomatic' to be something akin to the global politico-economic order. To use Deleuze and Guattari's parlance, we could say that an assemblage of diverse axioms - that is, specific politico-economic formations - constitutes the global axiomatic. 


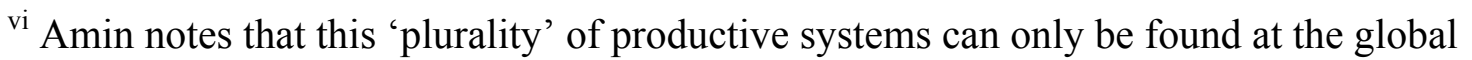
periphery. The core countries, in contrast, have a 'vocation to exclusiveness, that is to say, to the destruction of all precapitalist modes' (Amin 1973: 64; cited in Larrain 1989: 142).

\section{References}

Alliez, Éric, Claire Colebrook, Peter Hallward, Nicholas Thoburn and Jeremy Gilbert (2009) 'Deleuzean Politics? A Roundtable Discussion', New Formations 68, pp. 143-87.

Amin, Samir (1973) Le Développement inégal, Paris: Minuit.

Amin, Samir (1976) Unequal Development: An Essay on the Social Formations of Peripheral Capitalism, New York: Monthly Review Press.

Amin, Samir (1977) 'The End of a Debate', in Imperialism and Unequal Development, Samir Amin (ed.), Brighton, UK: Harvester Press, pp. 181-252.

Amin, Samir (1990) Delinking: Toward a Polycentric World, London: Zed Books.

Badiou, Alain (2000) Deleuze: The Clamor of Being, trans. Louise Burchill, Minneapolis: University of Minnesota Press.

Badiou, Alain (2009a) 'Existe-t-il quelque chose comme une politique deleuzienne ?', Cités : Philosophie, Politique, Histoire 40, pp. 15-20.

Badiou, Alain (2009b) Pocket Pantheon: Figures of Postwar Philosophy, trans. David Macey, London: Verso.

Baudrillard, Jean (1970) La société de la consommation, Paris: Gallimard.

Baudrillard, Jean (1972) Pour une critique de l'économie politique du signe, Paris: Gallimard.

Baudrillard, Jean (1973) Le Miroir de la production, Paris: Casterman.

Cardoso, Fernando Henrique and Enzo Faletto (1979) Dependency and Development in Latin America, trans. Marjory Urquidi, Berkeley and Los Angeles: University of California Press.

Deleuze, Gilles (1992) 'Postscript on the Societies of Control', October 59, pp. 3-7.

Deleuze, Gilles and Félix Guattari (1983) Anti-Oedipus: Capitalism and Schizophrenia, Vol. I, trans. Robert Hurley, Seem Mark and Helen R. Lane, Minneapolis: University of Minnesota Press. 
Deleuze, Gilles and Félix Guattari (1987) A Thousand Plateaus: Capitalism and Schizophrenia, Vol. II, trans. Brian Massumi, Minneapolis: University of Minnesota Press.

Dosse, François (2011) Gilles Deleuze and Félix Guattari: Intersecting Lives, trans. Deborah Glassman, New York: Columbia University Press.

Foster-Carter, Aidan (1978) 'The Modes of Production Controversy', New Left Review 107, pp. 47-77.

Frank, André Gunder (1969) Capitalism and Underdevelopment in Latin America, New York: Monthly Review Press.

Frank, André Gunder (1978) World Accumulation, 1492-1789, London: Macmillan.

Frank, André Gunder (1984) Critique and Anti-Critique, London: Macmillan.

Goodchild, Philip (1996) Deleuze and Guattari: An Introduction to the Politics of Desire, London: Sage.

Hallward, Peter (2006) Out of This World: Deleuze and the Philosophy of Creation, London: Verso.

Hardt, Michael and Antonio Negri (2000) Empire, Cambridge, MA: Harvard University Press.

Harvey, David (2007) A Brief History of Neoliberalism, Oxford: Oxford University Press.

Holland, Eugene W. (2011) Nomad Citizenship: Free-Market Communism and the SlowMotion General Strike, Minneapolis: University of Minnesota Press.

Holland, Eugene W. (2013) Deleuze and Guattari's A Thousand Plateaus: A Reader's Guide, London: Bloomsbury Academic.

Larrain, Jorge (1989) Theories of Development: Capitalism, Colonialism, Dependency, Cambridge: Polity.

Lazzarato, Maurizio (2012) The Making of Indebted Man, Los Angeles: Semiotext(e).

Lecerle, Jean-Jacques (2005) 'Deleuze, Guattari and Marxism', Historical Materialism 13:3, pp. 35-55.

Lyotard, Jean-François (1974) Economie libidinale, Paris: Minuit. 
Nail, Thomas (2012) Returning to Revolution: Deleuze, Guattari and Zapatismo, Edinburgh: Edinburgh University Press.

Palma, Gabriel (1981) 'Dependency and Development: A Critical Overview', in Dependency Theory: A Critical Reassessment, Dudley Seers (ed.), London: Allen \& Unwin, pp. 20-78.

Patton, Paul (1988) 'Marxism and Beyond: Strategies of Reterritorialization', in Cary Nelson and Lawrence Grossberg (eds), Marxism and the Interpretation of Culture, Champaign, IL: University of Illinois Press, pp. 123-40.

Patton, Paul (2000) Deleuze and the Political, London: Routledge.

Sibertin-Blanc, Guillaume (2016) State and Politics: Deleuze and Guattari on Marx, Los Angeles: Semiotext(e).

Surin, Kenneth (2009) Freedom Not Yet: Liberation and the Next World Order, Durham, NC: Duke University Press.

Thoburn, Nicholas (2003) Deleuze, Marx and Politics, London: Routledge.

Tynan, Aidan (2009) 'The Marx of Anti-Oedipus', Deleuze Studies 3, pp. 28-52.

Viveiros de Castro, Eduardo (2010) 'The Untimely Again', in Pierre Clastres: Archeology of Violence, trans. Jeanine Herman and Ashley Lebner, Los Angeles: Semiotext(e), pp. 9-51.

Wallerstein, Immanuel (1975) 'The Present State of the Debate on World Inequality', in World Inequality, Immanuel Wallerstein (ed.), Montreal: Black Rose Books, pp. 9-28. 